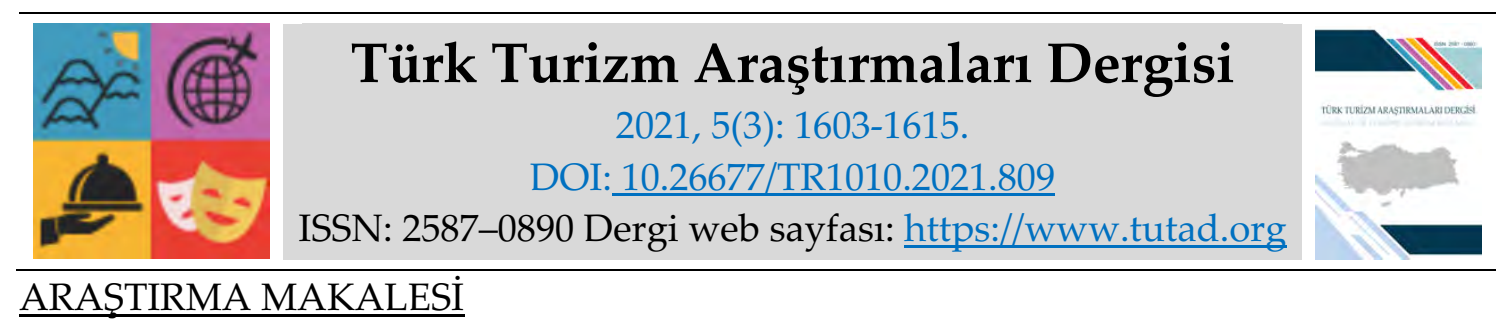

\title{
Covid-19 Salgınının Turist Rehberliği Mesleği Üzerine Etkileri: Çanakkale Rehberler Odası Örneği
}

Doç. Dr. Çiğdem ÖZKAN, Çanakkale Onsekiz Mart Üniversitesi, Ayvacık Meslek Yüksekokulu, Çanakkale, e-posta: cigdemozkan@comu.edu.tr

ORCID: https://orcid.org/0000-0002-9823-4117

Dr. Barış YEŞiLDAĞ, Bağımsız Araştırmacı, e-posta: yesildagbaris@gmail.com

ORCID: https://orcid.org/0000-0001-6772-5581

Öz

2019 yılı sonunda başlayıp 2021 yılında da devam etmekte olan Covid-19 salgını tüm dünyayı, insanlığı ve farklı birçok sektörü etkilemiştir. Covid-19 salgınının en fazla etkilediği sektörlerden birisi olan turizm sektörü ve paydaşları ve çalışanları büyük zorluklar yaşamaktadır. Küresel çapta önlemlerin alındığı ve özellikle seyahat kısıtlamalarının olduğu turizm sektörü içerinde çalışan turist rehberlerinin etkilenmesi kaçınılmazdır. Özellikle turizm destinasyonlarının tanıtılmasında çok önemli bir rol oynayan turist rehberliği mesleği salgın sürecinden etkilenmektedir. Bu çalışmada amaç, turist rehberlerinin salgın sürecinden ekonomik, sosyopsikolojik ve mesleki olarak etkilenme düzeylerini ortaya çıkarmaktır. Bu amaç doğrultusunda veri toplamak için nitel araştırmada veri toplama yöntemlerinde bir olan görüşme den yararlanılmıştır. Araştırmada kullanılan yarı yapılandırılmış görüşme formu 33 turist rehberine uygulanmıştır. Verilerin analizi için temalar oluşturmuştur. Oluşturulan temalara uygun olarak yapılmıştır. Araştırma sonuçlarına göre; turist rehberleri salgın sürecinden ekonomik, sosyopsikolojik ve mesleki anlamda olumsuz etkilenmiştir. Ekonomik anlamda gelir kayıpları yaşadıkları ve bu nedenle farklı işler yapmak zorunda kaldıkları veya birikimlerini harcadıklarını ifade etmişlerdir. Sosyo-psikolojik olarak moral bozukluğu yaşadıklarını ifade etmişlerdir. Son olarak mesleklerini çok sevdikleri halde farklı mesleklere yönelmeleri gerektiğini ifade etmişlerdir.

Anahtar Kelimeler: Covid-19 Salgını, Covid-19, Turist Rehberliği, Çanakkale.

Makale Gönderme Tarihi: 22.03.2021

Makale Kabul Tarihi: 01.09.2021

\section{Önerilen Atıf:}

Özkan, Ç. ve Yeşildağ, B. (2021). Covid-19 Salgınının Turist Rehberliği Mesleği Üzerine Etkileri: Çanakkale Rehberler Odası Örneği, Türk Turizm Araştırmaları Dergisi, 5(3): 1603-1615.

(C) 2021 Türk Turizm Araştırmaları Dergisi. 


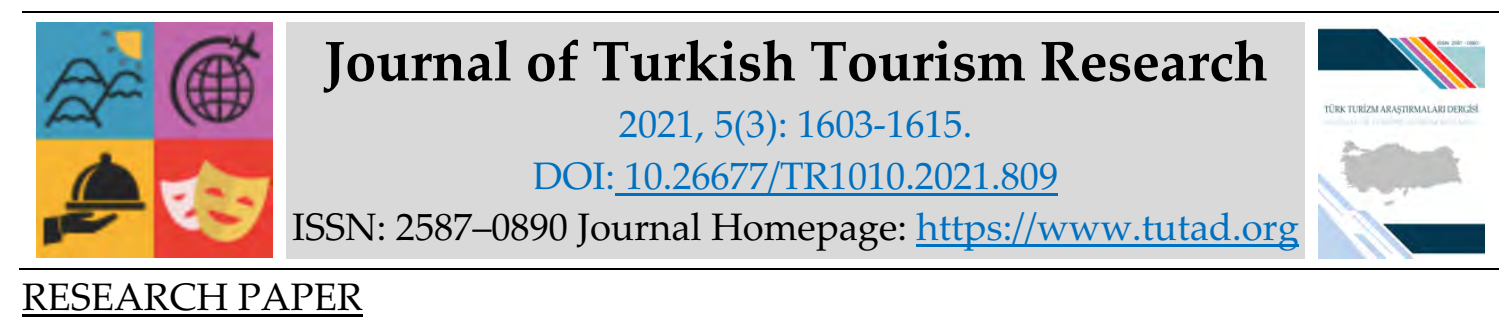

\title{
The Effects of the Covid-19 Outbreak on the Tourist Guiding Profession: The Case of Çanakkale Guides Chamber
}

Associate Prof. Dr. Çiğdem ÖZKAN, Çanakkale Onsekiz Mart University, Ayvacık Vocational School, Çanakkale, e-mail: cigdemozkan@comu.edu.tr

ORCID: https://orcid.org/0000-0002-9823-4117

Dr. Barış YEŞILDAĞ, Independent Researcher, e-mail: yesildagbaris@gmail.com

ORCID: https://orcid.org/0000-0001-6772-5581

\begin{abstract}
The epidemic of coronavirus, which started at the end of 2019 and continued in 2021, has affected the whole world, all humanity and all sectors. The tourism sector, which is one of the most affected by the coronavirus epidemic, and the stakeholders and sector employees in this sector are experiencing great difficulties. It is inevitable that tourist guides working in this sector will be affected in the tourism sector where global measures are taken and especially where travel restrictions are existing. The tourist guiding profession, which plays a very important role in promoting tourism destinations, is affected by the epidemic process. The aim of this study is to reveal the economic, socio-psychological and occupational exposure levels of tourist guides from the epidemic process. For this purpose, interview method, which is one of the qualitative research methods, was used to collect data. A semi-structured interview form which is used in this study was applied to 33 tourist guides. The analysis of the data was made in accordance with the themes created. According to the results of the research; It has been revealed that tourist guides have been negatively affected by the epidemic process in economic, socio-psychological and professional terms.
\end{abstract}

Keywords: Coronavirus Outbreak, Covid-19, Tourist Guide, Çanakkale.

Received: 22.03 .2021

Accepted: 01.09.2021

\section{Suggested Citation:}

Özkan, Ç. and Yeşildağ, B. (2021). The Effects of the Covid-19 Outbreak on the Tourist Guiding Profession: The Case of Çanakkale Guides Chamber, Journal of Turkish Tourism Research, 5(3): 1603-1615.

(C) 2021 Türk Turizm Araştırmaları Dergisi. 


\section{Gíriş}

2019 yılı sonunda Çin'in Hubei eyaletine bağlı Vuhan kentinde ortaya çıkan Covid-19, kısa süre içerisinde dünya çapında yayılan bir salgına dönüşerek, 215 ülkeye yayılmıştır. 14 Ocak 2020 itibariyle dünya genelinde 92. 862.638 kişi Covid-19'a yakalanmış, 1.988 .923 kişi hayatını kaybetmiştir (www.worldometers.info). Türkiye'de ise 2.355.839 kişi Covid-19'e yakalanmış, 23.325 kişi hayatını kaybetmiştir (www. covid19.saglik.gov.tr). Tüm dünya insanlığını sosyal, ekonomik, psikolojik açılardan derinden etkileyen Covid-19 salgını, konjonktürel dalgalanmalardan en fazla etkilenen sektörlerden biri olan turizm sektörünü de (Düzgün ve Kurt 2020: 18) derinden etkilemiştir (www.türsab.org.tr). 2020 yllında dünya genelinde birçok ülkede ekonomik daralma görülürken, Türkiye 2020 yllında 1,8 büyümüştür (www.dunya.com).

İkinci Dünya Savaşı, sonrasında küresel anlamda en hızlı gelişim gösteren sektörlerden biri turizm sektörü olmuştur. Birleşmiş milletler dünya turizm örgütü (B.M.D.T.O) verilerine göre 1950'li yıllarda dünya genelinde 25 milyon civarında uluslararası seyahat gerçekleştirilirken, 2019 yılında uluslararası seyahat sayısı 1 milyar 461 milyona uluslararası turizm kaynaklı gelirler ise 1.5 trilyon dolara ulaşmıştır (www.türsab.org.tr). Dünya Seyahat ve Turizm Konseyi (WTTC) verilerine göre ise turizm sektörünün dünya ekonomisine toplam katkısı 8,9 trilyon dolar seviyesinde olup, dünya genelindeki istihdamın yüzde 10'u (330 milyon) kişi turizm sektörü tarafından sağlanmaktadır (www.wttc.org). Covid-19 salgını sürecinde turizm sektörü gelir ve istihdam verilerine bakıldığında dünya genelinde yüzde 80 oranında düşüş yaşandığ görülmektedir (www.tureb.org.tr). Uluslararası düzeyde seyahat kısitlamaları nedeniyle ulaştırma işletmeleri, konaklama işletmeleri, seyahat endüstrisinde faaliyet yürüten tüm işletmeler faaliyetlerine ara vermek veya sonlandırmak zorunda kalmıştır. Turizm sektörü işletmeleri, paydaşları, çalışanları, işverenler Covid-19 sürecinden olumsuz anlamda etkilenmiştir.

Salgın sürecinde seyahat kısıtlamaları nedeniyle, seyahat acenteları, tur operatörleri faaliyetlerine ara vermiş ve söz konusu işletmelerde çalışanlar işsiz kalmıştır. Turist rehberleri de salgından en fazla etkilenen meslek grupları arasında yer almaktadır (Düzgün ve Kurt 2020: 18). Turist rehberleri bu süreçte ya çok az çalışmış ya da hiç çalışamamıştır. Bu kapsamda, bu çalışmada amaç, Covid-19 salgını sürecinde turist rehberlerinin ekonomik, sosyal ve psikolojik açıdan etkilenme düzeylerinin belirlenmesidir.

\section{LITERATÜR TARAMASI}

Dünya genelinde geçmişten günümüze yaşanan krizler, tüm sektörleri olduğu gibi turizm işletmeleri ve paydaşlarını da etkilemiştir. 11 Eylül 2001 terör saldırısından en çok etkilenen sektörlerden biri havacılık sektörüdür. 11 Eylül öncesinde ABD'de ATA (Air Transport Association) üyesi havayolu işletmeleri haftada yaklaşık 9 milyon yolcu taşırken, bu sayı 11 Eylül sonrasında yaklaşık \% 50 azalarak 5 milyon yolcu olmuştur. Taşınan yolcu sayısı 2000 yılında 45.988 iken, 2001'de 30.258'e düşerek doluluk oranları \%10.9 azalmıştır (Bükeç ve Çelik 2010). 2003 yılında yaşanan şiddetli akut solunum sendromu (SARS) salgını dolayısıyla Hong Kong turizm sektörünü önemli ölçüde etkilendiği ifade edilmektedir (Siu ve Wong, 2004).

2009 yılında domuz gribi pandemi olarak tanımlanmıştır ancak Covid-19'a göre etkileri daha hafif yaşanmıştır (Gössling vd., 2020). Russy ve Smith (2013) yaptığı çalışmada, Meksika turizmine domuz gribinin etkilerini incelemiş ve 5 yıllık süre içinde bir milyon deniz aşırı ziyaretçinin kaybedildiğini ifade etmiştir. Küresel iklim değişikliği, nüfus artışı dünya genelinde epidemik ve pandemik birçok hastalığın çıkmasına ve yayılmasına neden olmuştur. İspanyol Gribi (1918-19), Asya Gribi (1957), Hong Kong Gribi (1968), SARS (2002), Kuş Gribi (2009), MERS 
(2012), Ebola (2013-14) gibi salgın hastalıkların ortaya çıkmasında küresel iklim değişikliğinin etkisinin önemli bir faktör olduğunu ifade eden çalışmalar oldukça fazladır (Coker vd., 2011; Wu vd., 2017). Geçmişten günümüze kadar ortaya çıkan salgın hastalıklar, dünya genelinde veya bölgesel olarak seyahat ve turizm sektörü ve paydaşlarını ekonomik, sosyal düzeyde etkilemiştir (Russy ve Smith, 2013; Berry vd., 2015; Hon, 2013). Çeti ve Ünlüönen (2019) yaptıkları çalışmada SARS, kuş gribi, domuz gribi, ebola salgınının turizm sektörü üzerindeki etkilerini inceleyen çalışmasında, salgının görüldüğü ülkelerdeki turist sayılarının salgının yaşandığı yıl bir önceki yıla göre azaldığı bulgusuna ulaşmıştır.

2019 yılı sonunda ortaya çıkan ve 2020 yılında tüm dünyayı etkisi altına alan, Covid-19 küresel salgını nedeniyle uluslararası turizm varışları (geceleyen ziyaretçi) Ocak- Ekim 2020 arası 2019 yılının aynı dönemine kıyasla \%72 oranında düşmüştür (www.e-unwto.org).

2020 yılına ilişkin çeşitli turizm örgütlerinin (WTO gibi) istatistiksel araştırma raporlarında görüldüğü gibi, Covid-19 salgınından Konaklama Sektörü, Havacilık Sektörü, Kruvaziyer Sektörü, Toplantı, Kongre ve Fuar Organizasyonu Sektörü, Seyahat Acentaları ve Tur Operatörleri en çok etkilenen sektörler olmuştur. Tur operatörleri ve seyahat acentaları, havacılık ve konaklama sektörü ile birlikte turizm endüstrisinin en önemli paydaşlarından biridir. Kitlesel ve gruplar halinde seyahat hareketlerinin Covid-19 döneminde durma noktasına gelmesi, seyahat acentalarına ağır darbe vurmuştur (www.tursab.org.tr). 2019 yılı ile kıyaslandığında 2020 yılında Türkiye'ye gelen göre turist yüzde 75 azalarak 11.200 .882 kişi olmuştur (www.tursab.org.tr). Turist rehberleri tur operetörler ve seyahat acentaları için önemli bir bileşendir. Bu nedenle sektörde yaşanan gelişmeler turist rehberlerini de etkilemektedir.

Düzgün ve Kurt (2020) “Covid-19 salgını turist rehberleri üzerindeki etkileri: Ankara turist rehberleri odası örneği" adlı çalışmasında turist rehberlerinin salgın sürecinde ekonomik sıkıntılar yaşadığı, kendilerini güvensiz hissettikleri, turist rehberliği mesleğini akademik olarak yapmaya yönlendikleri sonucuna ulaşmıştır.

Papanikos (2020) tarafından Covid-19 sürecinin Yunanistan turizmi üzerine etkilerinin araştırıldığı çalışmada salgının Yunanistan turizmi zerinden çok büyük bir etki yaptığı görülmüş, Yunanistan turizm gelirlerinin savaş dışı bir dönemde bu kadar azaldığının görülmediği sonucuna ulaşılmıştır. Gössling ve diğerleri (2020) yaptıkları çalışmada, hava taşımacılığı, cruise gemi turizmi, konaklama sektörü ve seyahat endüstrisi işletmelerinde pandeminin etkilerinin yıkıcı olduğunu ifade etmiştir. Acar (2020) yaptığı çalışmada, yeni Covid-19 salgını nedeniyle ülke ekonomilerinde uzun süreli zararların oluşacağı ve bu zarardan turizm sektörünün doğrudan olumsuz etkileneceğini ifade etmiştir. Deb ve Nabi (2020) yapmış olduğu çalışmada Covid-19 salgınının turizm endüstrisinde daha önce yaşanmış krizlere kıyasla ekonomik ve sosyal açıdan olumsuz etkilerinin daha fazla olduğunu ifade etmiş̧ir. Ayrıca salgının etkilerinin 2-3 yil daha süreceğini öne sürmüştür.

\section{YÖNTEM}

Bu çalışmada nitel araştırma desenlerinden örnek olay deseni kullanılmıştır. Yarı yapılandırılmış görüşme tekniğine başvurulmuştur. Nitel araştırmalar genelde küçük gruplar üzerinde yapılmaktadır. Bununla beraber nitel araştırmalarda olgular ve durumlar derinlemesine analiz edilebilmektedir (Yıldırım ve Şimşek, 2013: 78). Araştırmanın örneklemini, 2021 yılında Çanakkale Rehberler Odasına bağlı rehberler oluşturmaktadır. Araştırmanın örneklemini oluşturan 33 kişinin \%36,3'ü (12 kişi) kadın, \%63,7'si (21 kişi) erkeklerden oluşmaktadır. Araştırma Haziran 2021 tarihinde yapılmıştır. 
Veri toplama aracı olarak, yarı yapılandırılmış nitel bir görüşme formu oluşturulmuştur. Bu araştırmada da kullanılan yarı yapılandırılmış görüşme tekniğĭ, araştırmacıya daha esneklik sağlayarak farklı bireylerden aynı tür bilgilerin alınmasına imkân vermektedir (Karagöz, 2019: 946). Görüşme formu, on açık uçlu sorudan meydana gelmektedir. Formun ilk diliminde turist rehberlerinin kişisel bilgilerini belirlemeye yönelik dört açık uçlu soru yer almaktadır. Araştırma formunun ikinci kısmında katılımcılara ilişkin demografik özellikleri belirlemeye yönelik sorular yer almaktadır. Rehberlere Google formlar üzerinde hazırlanan anket formu elektronik posta yoluyla gönderilmiş ve araştırmaya katılmayı kabul edenler ile Zoom üzerinden bağlanılarak çevirim içi ortamda görüşme yapılmıştır.

Araştırmada elde edilen verilerin analizi için içerik analizi tekniği kullanılmıştır. İçerik analizi, seçici, sınıflandırıcı ve nicelleştirici bir yöntem olarak salt bir betimleme ve tasvir aracı ya da tekniği değil, aksine çıarım yapma yoluyla sosyal gerçeğin belirli boyutlarını araştıran bir yöntemdir (Gökçe, 2006: 19). İçerik analizinde temel amaç, araştırma sonucunda elde edilen verileri açıklayabilecek kavramlara ve ilişkilere ulaşmaktır. Bu amacı gerçekleştirmek için yapılan işlem ise, birbirine benzeyen verileri belirli kavramlar ve temalar çerçevesinde bir araya getirmek ve bunları okuyucunun anlayabileceği bir biçimde düzenleyerek yorumlamaktır (Yildırım ve Şimşek, 2011: 227).

\section{BULGULAR}

Araştırmanın bu kısmında, katılımcılara yöneltilen sorular demografik özelliklere ilişkin ve ekonomik, sosyo-psikolojik ve rehberlik mesleğinin geleceğine ilişkin temalara yönelik sorular olmak üzere gruplandırılarak açıklanmıştır.

Tablo 1. Demografik Değişkenlere İlişkin Veriler

\begin{tabular}{|l|l|c|c|}
\hline \multicolumn{2}{|l|}{} & F & $\%$ \\
\hline \multirow{3}{*}{ Cinsiyet } & Kadın & 12 & 36,3 \\
\cline { 2 - 4 } Yaş & Erkek & 21 & 63,6 \\
\hline \multirow{3}{*}{ Medeni durum } & $25-40$ & 12 & 36,3 \\
\hline \multirow{3}{*}{ Mesleki Deneyim (Yll) } & $40-55$ & 10 & 30,3 \\
\cline { 2 - 4 } & $55-70$ & 11 & 33,3 \\
\hline & Evli & 25 & 75.7 \\
\cline { 2 - 4 } & Bekar & 7 & 24,2 \\
\hline & $1-10$ & 12 & 27,4 \\
\cline { 2 - 4 } & $10-20$ & 14 & 36,3 \\
\cline { 2 - 4 } & 20 ve üzeri & & 42,4 \\
\hline
\end{tabular}

Katılımcıların \%36,3'ü 25-40 yaş aralığında, \%30'3'ü 40-55 yaş aralığında ve \%33,3’ü $55-70$ yaş aralığındadır. Araştırmaya katılan turist rehberlerinin \%75,7'si evli ve \%24,2'si bekar olarak görülmektedir. Aynı zamanda, turist rehberi olarak çalışan katılımcıların mesleki deneyimlerinin $\% 27^{\prime} 4^{\prime}$ ü 1-10 yıl, \%30,3'üu 10-20 yıl ve yüzde 36,3'üu 20 ve üzeri yıl olduğu görülmektedir.

\section{Katılımcıların Kategorik Özelliklerine İlişkin Bulgular}

Çalışmada, katılımcılara "Salgın öncesi çıkılan tur çeşitleri", "Salgın öncesi çıkılan tur sayısı", "Salgın başlangıcından araştırmanın yapıldığı tarihe kadar çıkılan tur sayısı", "Salgın sürecinde geçim kaynakları", "Salgın sürecinde ekonomik destek alıp almama durumu", "Salgın sürecinde 
geçim kaynakları" gibi çoktan seçmeli sorular yöneltilerek, mevcut durum hakkında genel bir bilgi edinilmeye çalışılmıştır.

Tablo 2. Salgın Öncesi Çıkılan Tur Çeşitleri

\begin{tabular}{|l|c|c|}
\hline Tur Çeşitleri & F & $\mathbf{\%}$ \\
\hline Günübirlik Turlar (Şehitlik ve Troia) & 17 & 51,5 \\
\hline Kültür Turları & 10 & 30,3 \\
\hline Anadolu Turları & 8 & 24,2 \\
\hline Bölgesel Turlar & 5 & 15,1 \\
\hline Paket Turlar & 2 & 6,0 \\
\hline Gemi (Cruise) Turları & 1 & 3,0 \\
\hline
\end{tabular}

Not: Katılımcılar birden fazla seçenek işaretleyebilmektedirler.

Tablo 2'ye göre araştırmaya katılan turist rehberlerinin $\% 51,5$ 'i günübirlik (Şehitlik ve Troia) turlara çıkmaktadır. Bu oran bölgesel rehberlerin genelde kendi bölgesinde yer alan turlara çıktıklarını göstermektedir. Bununla beraber araştırmaya katılan turist rehberlerinin \%24,2'si Anadolu turlarına ve \%30,3'ü kültür turlarına çıkmaktadır.

Salgın öncesi çıkılan turlara K3 kod isimli turist rehberinin cevabı şu şekildedir: "Ben Çanakkale bölgesinde yaşıyorum ve genelde günlük turları tercih ediyorum". Çanakkale Rehberler Odası'na bağlı turist rehberlerinin genelde Çanakkale'de yer alan şehitlik turu ve Troia turlarına gittikleri anlaşılmaktadır.

Tablo 3. Salgın Öncesi Çıkılan Tur Sayısı

\begin{tabular}{|l|c|c|}
\hline Tur Sayısı & F & \% \\
\hline $100-150$ (gün & 12 & 36,3 \\
\hline $20-50$ (gün) & 6 & 18,1 \\
\hline $50-100$ (gün) & 5 & 15,1 \\
\hline $150-200$ (gün) & 5 & 15,1 \\
\hline 200 ve üzeri (gün) & 5 & 15,1 \\
\hline
\end{tabular}

Tablo 3'de araştırmaya katılan turist rehberlerinin salgın öncesi yıl boyunca gün bazında çıtıkları tur sayısı görülmektedir. Buna göre araştırmaya katılan turist rehberleri \%36,3'ü salgın öncesi yıl boyunca 100-150 gün aralığında tura çıkmaktadır. Cevaplar incelendiğinde araştırmaya katılan 5 turist rehberinin bir yılda 200 gün ve üzeri tura çıtıkları tespit edilmiştir.

Tablo 4. Salgın Başlangıcından Araştırmanın Yapıldığı Tarihe Kadar Çıkılan Tur Sayısı

\begin{tabular}{|l|c|c|}
\hline Tur Sayıs1 & F & $\mathbf{\%}$ \\
\hline 0 (gün) & 12 & 36,3 \\
\hline $0-5$ (gün) & 12 & 36,3 \\
\hline $5-10$ (gün) & 6 & 18,1 \\
\hline 15 ve üzeri (gün) & 5 & 15,1 \\
\hline $10-15$ (gün) & 2 & 6,0 \\
\hline
\end{tabular}


Tablo 4'de araştırmaya katılan turist rehberlerinin Covid-19 salgınının başlangıcından bugüne kadar çıktıkları toplam tur sayısı gün bazında görülmektedir. Tablo 4'e göre Covid-19 salgınının başlangıcından bugüne kadar hiç tura çıkamayan rehber sayısı \%36,3 ile 12 kişidir.

Covid-19 salgınının başlangıcından bugüne kadar 0-5 gün arası tura çıkabilen rehber sayısı $\% 36,3$ oranla 12 kişidir. Tablo 4'e göre hiç tura çıkamayan ya da 0-5 gün arası tura çıkabilen turist rehberi sayısı 24 olmuştur. Buradan Çanakkale Rehberler Odası'na bağlı turist rehberlerinin salgından çıkılan tur sayısı açısından oldukça olumsuz etkilendikleri sonucuna varılabilir. Benzer şekilde Düzgün ve Kurt (2020) turist rehberlerine yönelik yaptıkları çalışmada, salgın sürecinde katılımcıların büyük çoğunluğunun hiçbir tura katılmadıklarını ifade etmiştir.

Tablo 5. Salgın Sürecinde Geçim Kaynakları

\begin{tabular}{|l|c|c|}
\hline Geçim Kaynakları & F & \% \\
\hline Birikimler & 10 & 30,3 \\
\hline Alternatif - Farklı İş & 9 & 27,2 \\
\hline Aile-Eş Desteği & 7 & 21,2 \\
\hline Emekli Maaşı & 7 & 21,2 \\
\hline Kredi ya da Borç & 5 & 15,1 \\
\hline
\end{tabular}

Tablo 5'da araştırmaya katılan turist rehberlerinin Covid-19 salgınının başlangıcından bugüne kadar geçimlerini nasıl sağladıkları görülmektedir. Tablo 5'e göre Covid-19 salgınının başlangıcından bugüne araştırmaya katılan turist rehberlerinin \%30,3'ü daha önce yapmış olduğu birikimleri kullanarak geçimini sağlamıştır. Çanakkale Rehberler Odası'na bağlı turist rehberlerinin \%27,2'si alternatif işler yaparak farklı mesleklere yönelmiş ve geçimini sağlamıştır. Araştırmaya katılan turist rehberlerinin \%21'2'si ailesinden ya da eşinden destek alarak geçimini sağlamıştır. Turist rehberlerinin \%21'2'si emekli maaşı sayesinde geçimini sağlamıştır. Turist rehberlerinin \%15,1'i kredi çekerek ya da borç alarak geçimini sağlamıştır.

Covid-19 salgını sürecinde geçiminizi nasıl sağladınız? Sorusuna K5 kod isimli katılımcı şu şekilde yanıt vermiştir: "Farklı mesleklerde çalışmak zorunda kalarak bakkalda eleman olarak günlük 100 TL kazanarak ve ev kirası ödeyerek geçinmeye çalışıyoruz. Rehberlere özel denilen Banka kredisi de çımadı".

K6 kod isimli katılımcı cevabı şu şekildedir: "Küçük bir miktar birikmiş paramızı kullandık. Kredi çektik, harcamaları en aza düşürerek ederek kredi kartına yüklendik". Benzer şekilde Düzgün ve Kurt (2020) yaptıkları çalışmada, turist rehberlerinin geçim sıkıntısı yaşadıklarını bunun için birçok rehberin alternatif işler yaptıkları, birikimlerini kullandıkları veya kiralık evlerini kapatarak ailelerinin yanlarına gittiklerini ifade etmiştir.

Tablo 6'da salgın sürecinde Çanakkale Rehberler Odası'na bağlı turist rehberlerinin devlet tarafından sağlanan nakdi yardım alıp almadıkları görülmektedir.

Tablo 6. Salgın Sürecinde Nakdi Yardım Alıp Almama Durumu

\begin{tabular}{|l|c|c|}
\hline & F & $\mathbf{\%}$ \\
\hline Nakdi yardım aldım & 6 & 18,1 \\
\hline Nakdi yardım almadım & 27 & 81,8 \\
\hline
\end{tabular}


Tablo 6 incelendiğinde araştırmaya katılan turist rehberlerinin \%81,8 gibi büyük bir çoğunlukla devlet tarafından sağlanan nakdi yardımı almadıkları görülmektedir. Doğancılı (2020) çalışmasında, salgın sonrasında Türkiye'de ortaya konulan destek uygulamalarını incelemiş ve seyahat acentaları, turist rehberleri ve ulaştırma sektörü için yeterli düzeyde destek verilmediği sonucuna ulaşmıştır. Benzer şekilde İbiş (2020) seyahat acentalarının devletten yeterli desteği alamadığını ifade etmiştir.

\section{Covid-19 Salgının Turist Rehberleri Üzerindeki Ekonomik, Sosyo-Psikolojik ve Mesleğin Geleceğine Yönelik Etkilerine İlişkin Temalar}

Yapılan görüşmelerin analizi sonrasında salgının turist rehberleri üzerine etkileri; ekonomik etkileri, sosyo-psikolojik etkileri ve mesleki beklenti temaları altında toplanmıştır. Yapılan görüşme sonucunda ekonomik etkilerine yönelik bulgular aşağıdaki gibidir.

\section{Tema 1: Ekonomik Etkiler}

K3 kod isimli katılımcı Covid-19 salgınının rehberlik mesleğine olan ekonomik etkilerini şu şekilde anlatmıştır: "Meslektaşlarımız ve ben ekonomik anlamda oldukça olumsuz etkilenmiştir. Özellikle tek geçim kaynağı rehberlik olan benim gibi kişiler mecburen farklı alanlarda iş arama zorunluluğunda kalmıştır. Kendisi ve ailesinin geçimi için taksici olan var, inşaatta bekçi olan var, benim gibi bakkalda eleman olarak çalışan da var".

K21 kod isimli katılımcı "Salgın sürecinde en çok etkilenen meslek gruplarının başında mesleğimiz gelmektedir. Meslektaşlarımızın hemen hemen \%95 i 2019 Ekim ayından bu tarafa gelir elde edememişler, büyük oranda maddi kayba uğramışlardır. Tur araçlarının yolcu sayısı \%50 oranında azaltılmış dolayısıyla zaten çok çok azalan tur sayısının üzerine müşteri sayısının azalması da eklenince tur fiyatları artı̧̧ göstermiş maliyeti düşürmek amactyla acenteler rehberlere taban ücret altı ücret teklif etmeye başlamıştır". İfadelerini kullanmıştır.

K29 kod isimli katılımcı “Tamamen olumsuz yönde etkilenmiştir. Pandemi ve kısıtlamalardan dolayı tur faaliyetleri gerçekleşmediği için rehberler işsiz kalmıştır".

Araştırmaya katılanların 18'i $(\% 57,5)$ salgın sürecinde turların iptal olduğunu, turların ve işlerinin azaldığını ve bu nedenle gelirlerinde ciddi bir azalma yaşadıklarını belirtmiştir. Katılımcıların tamamı salgının ekonomik sıkıntılara neden olduğunu belirtmiştir. Benzer şekilde Düzgün ve Kurt (2020) yaptıkları çalışmada, katılımcıların tamamının maddi yönden zor duruma düştükleri sonucuna ulaşmıştır. Bahar ve İlal (2020) yaptıkları çalışmada salgın sürecinin turizm sektöründe talep ve istihdam kayıplarına yol açacağını sonucuna ulaşmıştır.

\section{Tema 2: Sosyo-Psikolojik Etkileri}

K21 adlı katılımcı "Mesleğe başladığım günden bugüne kadar birçok olumsuz durum yaşadığını fakat bu kadar uzun süren bir işsizlik yaşamadığını bu nedenle psikolojisinin bozulduğunu ifade etmiştir.

K28 kod isimli katılımc1, "Ailelerimiz hem psikolojik hem de moral açısından olumsuz etkindi çünkü geçim sıkıntısını çok şiddetli bir şekilde hissetmeye ve bunun getirdiği sorunlarla başa çıkmaya çalışıyoruz. Mücadele etmeye devam ediyoruz" ifadelerini kullanmıştır. Benzer şekilde, Düzgün ve Kurt (2020) yaptıkları çalışmada Covid-19 salgınının rehberleri sosyo-psikolojik anlamda olumsuz etkilediğini ifade etmiştir. 
Katılımcıların \%6'sı salgının tedirginlik, korku ve endişeye neden olduğunu söylemiştir. Katılımcların büyük çoğunluğu (19) kişi aile bireylerinin salgın sürecinden maddi ve manevi olarak etkilendiklerini ifade etmişlerdir. Katılımcılardan 3 kişi aile olarak birbirimize daha fazla kenetlendik demiştir. Katılımcıların tamamı salgın sürecinden psikolojik anlamda olumsuz etkilendiklerini ifade etmiştir.

\section{Tema 3: Mesleğin Geleceğine Yönelik Etkileri}

K15 kod isimli katılımcı "Seyahatler, uçak seferleri bitince rehberlik mesleği de bitti. 42 ylllı rehberlik hayatımda birçck kriz yaşadık, işlerimiz azaldı. Ama böyle bir şey hiç yaşamadık. Rehberlik mesleği dibe vurdu". İfadelerini kullanmıştır.

K10 kod isimli katılımcı Covid-19 salgınının rehberlik mesleğine olan etkilerini şu şekilde anlatmıştır: "Salgın nedeniyle turizm hareketleri güvenli bulunmuyor. Bu yüzden oldukça olumsuz bir şekilde etkilendi. Turlarda sosyal mesafe vs., sokağa çıkma yasakları gibi faktörler, turizm hareketlerini ihtiyaç dişi kabul etti. Böylece rehberlik mesleği de birinci dereceden olumsuz olarak etkilendi".

Katılımcıların \%36,3'ü rehberlik mesleğinin geleceğini tehlikede görmektedir, \%21,2'si rehberlik dışında farklı bir meslek yapmaları gerektiğini hissetmektedir. Katılımcıların \%18,1'i tekrar çalışabilme endişesi taşımaktadır, \%12,1'i rehberlik mesleğini özledikleri belirtmiştir.

K1 kod isimli katılımcı Covid-19 salgını sürecinde mesleğiniz ile ilgili neler hissettiniz sorusuna şu şekilde cevap vermiştir: "Hem anlatma özlemi hem o yerlerde bulunma isteği. Bundan sonra bu meslek ne şekilde devam edecek, sorusu... Tekrar gruplar gelecek mi endişesi... ".

Katılımcıların \%63,6'sı farklı bir meslek yapılabileceğini, farklı bir mesleğe yönelmenin salgın sürecinde zorunluluk olduğu görülmektedir. Katılımcıların \%36,3'sının farklı bir meslek yapamayacaklarını ifade etmiştir.

Yapılan görüşme sonucunda araştırmaya katılan turist rehberlerinin \%24,2'si salgın sürecinin mesleği olumsuz etkilediğini belirtmiştir. Katılımcıların \%6'sı farklı bir meslek arayışına girdiğini söylemiştir. Benzer şekilde Düzgün ve Kurt (2020) turist rehberlerine yönelik yaptıkları çalışmada, katılımcıların \%60'ının farklı bir meslek yapmayı düşündükleri sonucuna ulaşmıştır. Kiper vd. (2020) turizm akademisyenlerine yönelik yaptığı çalışmada katılımcıların büyük çoğunluğunun turizm mesleğinin salgın sürecinden ekonomik, sosyal ve politik anlamda tehdit ile karşı karşıya kaldığı sonucuna ulaşmıştır.

Araştırmaya katılan katılımcların, \%36,3'ü salgın sonrasında turların artacağını ve yoğunlaşacağını düşünmektedir. \%21,2'si salgın sonrasında turların olacağını ancak yoğunluğun olmayacağını, \%12,1'i salgın sonrası münferit, bireysel ve özel turların artacağını, \%12,1'i salgın sonrası büyük otobüslerle yapılan kitle turları olmayacağını düşünmektedir. Bununla beraber katılımcıların \%9,0'ı salgın sonrası sanal turlar / dijital turların artacağını düşünmektedir.

K19 kod isimli katılımcı salgın sonrası rehberlik mesleğinin geleceği ile ilgili soruya şu şekilde cevap vermiştir: "Evlerinde neredeyse hapis kalan insanların, özellikle maaşlı ve gelir kaybı yaşamamış kişilerin çılgınca seyahat edeceğini ve rehber ihtiyacının bir süre sonra eskisi kadar olmasa da kazanç elde etmeye başlayacağını düşünüyorum".

K19 kod isimli katılımcı salgın sonrası rehberlik mesleğinin geleceği ile ilgili soruya şu şekilde cevap vermiştir: "Turların olması açısından iki yönlü değişiklik olabilir. Illk olarak gezmeyi özleyen turistler yığllma gösterebilir ki bu da olumludur. Saniyen virüsün psikolojik etkisi insanlarda endişe yarattı̆̆ından turistler çekinik davranarak gezilere katılmada azalma olabilir. Bunların dışında dijital rehberlik uygulamalarının artacă̆ını düşünüyorum". 


\section{SONUÇ ev ÖNERILLER}

Çanakkale Turist Rehberleri Odasına kayıtlı rehberler üzerinde yapılan bu çalışmanın sonuçlarına göre; turist rehberleri Koranavirüs salgını sürecinde ekonomik anlamda olumsuz etkilenmiştir. Benzer şekilde Düzgün ve Kurt (2020:18) turist rehberlerine yönelik yaptıkları çalışmada Mart-Nisan aylarını bekleyen rehberlerin tüm dünyada ve Türkiye'de hızla yayılan Covid-19 salgını nedeniyle büyük ekonomik sıkıntılar içerisinde girdikleri sonucuna ulaşmıştır. İbiş (2020) İstanbul'da faaliyet yürüten seyahat acentası yetkilileri ile yaptıkları görüşmede, acentaların salgın sürecinden ekonomik anlamda ciddi şekilde etkilendiklerini, gelirlerinin tamamen kesildiğini fakat sabit maliyetlerinin halen devam ettiğini, maliyetleri ödeyemez hale geldikleri sonucuna ulaşmıştır. Seyahat acentaları, tur operatörleri ve çalışanlarına yönelik yapılan çalışmalardan elde edilen sonuçlar incelediğinde, söz konusu işletme sahip ve çalışanlarının ekonomik olarak ciddi anlamda olumsuz etkilendikleri, gelir kaynaklarının kesildiği ve bu nedenle başka işlere yöneldikleri sonucuna ulaşılmıştır.

Çanakkale rehberler odasına bağlı turist rehberleri salgın sürecinden sosyo-psikolojik olarak gerek kendilerinin gerekse de ailelerinin olumsuz etkilendiklerini ifade etmişlerdir. Benzer olarak Düzgün ve Kurt (2020) turist rehberlerine yönelik yaptıkları çalışmada rehberlerin kendilerini güvensiz hissettikleri soncuna ulaşmıştır. Bunun yanı sıra araştırma sonuçlarına göre, araştırmaya katılan rehberlerin meslekleri ile ilgili kaygılarının arttığını, mesleğin geleceğinin birkaç yıl düzelemeyeceği ifade edilmektedir. Düzgün ve Kurt (2020) turist rehberlerine yönelik yaptıkları çalışmada rehberlerin mesleklerini akademik olarak yapmaya yönlendikleri sonucuna ulaşmıştır.

Araştırmaya katılanların \% 36,3'ü salgın sonrasında turların artacağını ve yoğunlaşacağını ifade etmiştir. \% 21,2'si salgın sonrasında turların olacağını fakat yoğunluğun olmayacağını, \% 12,1'i salgın sonrasında münferit, bireysel ve özel turların artacağını, \% 12.1'i salgın sonrasında büyük kapasiteli otobüsler ile yapılan turların azalacağını düşünmektedir. Bununla beraber katılımcıların \%'u salgın sonrasında salan turlar/dijital turların artacağını düşünmektedir. Türker ve Karaca (2020) turist rehberleri üzerinde yaptığı çalışmada, Covid-19 süreci sonucunda hijyen, bireysel seyahatler, küçük gruplar, sosyal mesafe ve aktif yönetim konularının turist rehberliği mesleğinde ön plana çıkacağını ifade etmiştir. Özçoban (2020) Covid-19 salgınıyla birlikte bireysel seyahatleri ve alternatif turizm çeşitlerine yönelik talebin artacağını ifade etmiştir.

Doğancılı (2020) çalı̧̧masında, salgın sonrasında Türkiye'de ortaya konulan destek uygulamalarını incelemiş ve seyahat acentaları, turist rehberleri ve ulaştırma sektörü için yeterli düzeyde destek verilmediği sonucuna ulaşmıştır. Benzer şekilde İbiş (2020) seyahat acentalarının devletten yeterli desteği alamadığını ifade etmiştir.

2020 yaz döneminde bireyleri tatile yönlendirmek için sunulan tatil kredilerinin yetersiz düzeyde olması, artan tatil fiyatları nedeniyle beklenen düzeyde konaklama gerçekleşmemiştir. Bunun sonucuna turizm sektörü paydaşları 2020 genelinde ekonomik kayıplar yaşamıştır. Konjonktürel dalgalanmalardan en fazla etkilenen sektörlerden biri olan turizm sektörü ve paydaşlarının bu tip olağanüstü durumlardan etkilenme düzeylerini aza indirebilmek için devlet desteğinin olması gerektiği ifade edilebilir. Salgın süresince turizm sektöründe çalışan üst, orta ve alt düzeyde tüm çalışanlar işini kaybetmiş veya kısmı zamanlı çalışmak zorunda kalmıştır. Kamu desteğinin en fazla olması gereken meslek grupları arasında turizm sektörü gelmektedir. Bundan sonraki süreçte günümüzde yaşananların tekrar etmemesi için belirli bir kamu kaynağının turizm sektörü için ayrılması gerektiği ifade edilebilir. Bakar ve Rosbi (2020), yaptıkları çalışmada turizme yönelik talepte azalma yaşanacağını ifade etmiştir ve gelinen noktada yapılan çalışmanın bulguları desteklenmektedir. Bu nedenle devletlerin önlem alması gerektiğini ifade etmiştir. 
Araştırmadan elde edilen bulgulara göre öneriler aşağıdaki gibi özetlenebilir;

- Konjonktürel dalgalanmalarından en fazla etkilenen sektörlerden biri olan turizm sektörü işletmeleri ve çalışanlarının devletler tarafından ayrı bir fon ayrılarak uzun vadede desteklenmesi gerektiği ifade edilebilir.

- Gelecekte turizm sektöründe çalışan bireylerin çalışma koşulları ve ücret politikaları ile ilgili bir kurumun olması gerektiği ifade edilebilir.

- Covid-19 salgın sürecinden etkilenen seyahat, ulaştırma ve konaklama sektörünün özel teşvik paketleri ile yeniden canlanmasını sağlamak üzere fon kurulması gerekmektedir.

- Turist rehberlerine yönelik psikolojik destek birimlerinin oluşturularak, sorunlarının dinlenmesi ve çözüm önerileri geliştirilebilir.

- Salgın sonrasında bireysel turlara yönelik farklı paketler hazırlanarak, tüketicilerin farklı beklenti ve istekleri karşılanabilir.

$\mathrm{Bu}$ çalışma Çanakkale iline bağlı turist rehberleri üzerinde yapılmışır. Salgın sürecinin etkilerinin daha geniş kapsamda değerlendirilebilmesi için diğer turizm sektörü işletmeleri ve çalışanlarına yönelik çalışmaların yapılması gerektiği ifade edilebilir.

\section{KAYNAKÇA}

Acar, Y. (2020). Yeni Covid-19 Salgını ve Turizm Faaliyetlerine Etkisi, Güncel Turizm Araştırmaları Dergisi, 4(1), 7-21.

Aydın, B. ve Doğan, M. (2020). Yeni Covid-19 (COVID-19) Pandemisinin Turistik Tüketici Davranışları ve Türkiye Turizmi Üzerindeki Etkilerinin Değerlendirilmesi, Pazarlama Teorisi ve Uygulamaları Dergisi, 6(1), 93-115.

Bahar, O. ve Çelik İlal, N. (2020). Covid'un Turizm Sektörü Üzerindeki Ekonomik Etkileri, The, International Journal of Social Sciences and Education Research, 6(1), 125-139.

Bakar, N. A. and Rosbi, S. (2020). Effect of Covid-19 Disease (COVID-19) to Tourism Industry, International Journal of Advanced Engineering Research and Science, 7(4), 189-193.

Berry, B., Gamieldien, J., and Fielding, B. C. (2015). Identification of New Respiratory Viruses in The New Millennium, Viruses, 7(3), 996-1019. https://doi.org/10.3390/v7030996

Bükeç, C. M. ve Erdoğan D. (2010). 11 Eylül Sonrası Döneminde Havacılıkta Güvenlik ve İşbirliği Anlayışındaki Küresel Değişim, 3. Ulusal Havacılık ve Uzay Konferansı, Anadolu Üniversitesi.

Coker, R. J., Hunter, B. M., Rudge, J. W., Liverani, M., and Hanvoravongchai, P. (2011). Emerging infectious diseases in southeast Asia: regional challenges to control, The Lancet, 377(9765), 599609. https://doi.org/10.1016/S0140- 6736(10)62004-1

Çeti, B. ve Ünlüönen, K. (2019). Salgın Hastalıklar Sebebiyle Oluşan Krizlerin Turizm Sektörü Üzerindeki Etkisinin Değerlendirilmesi, AHBVÜ Turizm Fakültesi Dergisi, 22(2), 109-128.

Demir, M., Günaydın, Y. ve Demir, Ş.Ş. (2020). Coronavirüs (Covid-19)'un Türkiye'de Turizm Üzerindeki Öncüllerinin, Etkilerinin ve Sonuçlarının Değerlendirilmesi, International Journal of Social Sciences and Education Research, 6(1), 80-107.

Doğancılı, O.S. (2020). Covid-19 Sonrası Turizm Destekleri, Türk Turizm Araştırmaları Dergisi, 4(3), 2808-2820.

Düzgün E. ve Kurt A. (2020). Covid-19 (Covid-19) Salgının Turist Rehberleri Üzerindeki Etkileri: Ankara Turist Rehberleri Odası Örneği, KSBD, 12(23), 18-38. 
Gökçe, O. (2006). İçerik Analizi: Kuramsal ve Pratik Bilgiler. Ankara: Siyasal Kitabevi.

Gössling, S., Scott, D. and Hall, C. M. (2020). Pandemics, Tourism and Global Change: A Rapid Assessment of COVID-19, Journal of Sustainable Tourism, 29(1). 1-20.

Hon, K. L. (2013). Severe respiratory syndromes: Travel history matters. Travel Medicine and Infectious Disease, 11(5),285-287. https://www.internationalsos.com/pandemicsites/pandemic/home/2019-ncov/ncov-travel-restrictionsflight-operations-and screeninghttps://doi.org/10.1016/j.tmaid.2013.06.005

https://covid19.saglik.gov.tr/TR-66935/genel-Covid-19tablosu.html?gclid=Cj0KCQiA9P_BRC0ARIsAEZ6irjK0W92OoCyILwsZFwVYEK5fnBWDtuQ Y0cnMOr4pxELeBiVUO15xfoaAh7OEALw_wcB Erişim Tarihi: 10.01.2020

https://www.dunya.com/ekonomi/turkiye-ekonomisi-2020de-yuzde-18-buyudu-haberi-612659. Erişim Tarihi: 13.04.2021

https://www.e-unwto.org/doi/epdf/10.18111/wtobarometereng.2020.18.1.7 Erişim Tarhihi: 04.05.2021

https://www.tursab.org.tr/istatistikler/turist-sayisi-ve-turizm-geliri Erişim Tarihi: 13.01.2020

https://www.worldometers.info/coronavirus/ Erişim Tarihi: 02.01.2020

https://www.worldbank.org/tr/country/turkey/publication/economic-monitor. Erişim Tarihi: 12.01.2020

https://wttc.org/Research/Economic-Impact. Erişim Tarihi: 12.01.2020

İbiş, S. (2020). Covid-19 Salgının Seyahat Acentaları Üzerine Etkisi, Safran Kültür ve Turizm Araştırmaları Dergisi, 3(1), 85-98.

Karagöz, Y. (2019). SPSS ve AMOS Uygulamalı Bilimsel Araştırma Yöntemleri ve Yayın Etiği, Nobel Yayıncilık, Ankara.

Kiper, V. O., Saraç, Ö., Çolak, O. ve Batman, O. (2020). Covıd-19 Salgınıyla Oluşan Krizlerin Turizm Faaliyetleri Üzerindeki Etkilerinin Turizm Akademisyenleri Tarafından Değerlendirilmesi, Balıkesir Üniversitesi Sosyal Bilimler Enstitüsü Dergisi, 23(43), 527-551.

Özçoban, E. (2020). Koronavirüs'ün (Covid-19) Turizm Sektörü Üzerindeki Etkileri ve Türkiye'nin Kırsal Turizm Potansiyeli Üzerine Bir Analiz, Electronic Turkish Studies, 15(4), 853866.

Papanikos, G.T. (2020). The Impact of the Covid-19 Pandemic on Greek Tourism, Athens Journal of Tourism, 7(2), 87-100.

Russy, D. and Smith, R. (2013). The Economic Impact of H1N1 on Mexico's Tourist and Pork Sectors, Health Economics, 22(7), 824-834.

Siu, A. and Wong, Y. R. (2004). Economic Impact of SARS: The Case of Hong Kong, Asian Economic Papers, 3(1), 62-83.

Türker, A. ve Karaca, K.Ç. (2020). Yeni Tip Koronavirüs (Covid-19) Salgını Sonrası Turizm ve Turist Rehberliği, Turist rehberliği Nitel Araştırmalar Dergisi, 1(1), 1-19.

Yıldırım, A. Ve Şimşek, H. (2013). Sosyal Bilimlerde Nitel Araştırma Yöntemleri, Seçkin Yayıncılık, Ankara. 
Wu, T., Perrings, C., Kinzig, A., Collins, J. P., Minteer, B. A., and Daszak, P. (2017). Economic Growth, Urbanization, Globalization and The Risks of Emerging Infectious Diseases in China: A Review, Ambio, 46(1), 18-29. 